\title{
Библиотека на сцени: Развој визије Градске библиотеке Чачак као места окупљања заједнице у 2019. години
}

\author{
Богдан Трифуновић \\ btrifunovic@gmail.com \\ Марија Радуловић \\ marijaradulovic3@gmail.com \\ Градска библиотека „Владислав Петковић Дис” Чачак
}

\begin{abstract}
Сажетак
Рад приказује иновативне програме и активности Градске библиотеке у Чачку који су реализовани кроз партнерство са широм друштвеном заједницом, као основом развоја нове визије Библиотеке чије је гесло „Библиотека на сцени”. Нова зграда Библиотеке, отворена у марту 2019. године, у тежњи да постане центар окупљања локалне заједнице и тако прошири своје капацитете, промовисана је на атрактиван и неуобичајен начин кроз две активности. То су били програми „Буди наша најјача карика: преселимо библиотеку заједно” и „Ко некад у осам: Дом ЈНА и забава у Чачку”, којима је зграда дошла у поље интересовања појединаца који раније нису користили услуге Библиотеке. Наведени програми су организовани у функцији развоја нове визије Библиотеке и интензивније сарадње са појединцима, удружењима, организацијама итд. То је довело до пораста броја активних чланова установе, бројније публике на осталим програмима и знатно веће присутности установе у јавном и медијском простору локалне заједнице.
\end{abstract}

Кључне речи: Градска библиотека „Владислав Петковић Дис”, Чачак, односи с јавношћу, сарадња, партнерства, завичајна баштина, изложбе, програми

Увод

Градска библиотека „Владислав Петковић Дис“ у Чачку од марта 2019. године смештена је у реконструисаном и адаптираном здању некадашњег Дома војске, раније Дома Југословенске народне армије (Дом ЈНА). Зграда Дома ЈНА саграђена је почетком 60-их година 20. века у центру града и свечано отворена 22. децембра 1962. године, као један од најрепрезентативнијих објеката савремене архитектуре у граду који се убрзано модернизовао.

Иако војни објекат, Дом ЈНА је у првој деценији свог постојања био један од најзначајнијих центара културних и забавних садржаја у Чачку. У време када је отворен, градске установе културе биле су још увек недовољно развијене, са малим бројем запослених и неодговарајућим простором, а Дом културе, отворен 1971. године као највећа установа културе у граду, није ни постојао. Услед таквих околности, Дом ЈНА се убрзо профилисао као место где су, између осталог, организовани забаве, игранке, концерти, матинеи, изложбе и други културнозабавни садржаји. Играо се билијар и стони тенис, а куглана је била посећена до касно увече. Такође, ту су одржани неки од првих концерата рок музике у Чачку, средини која, судећи по новинским чланцима из тог времена, није здушно прихватила нови музички правац са запада. У Дому ЈНА гостовали су неки од најпопуларнијих југословенских поп и рок извођача тог времена - Боба Стефановић, „Црвени кораљи”, „Златни дечаци” и други. Почеци чачанских рокенрол бендова, попут „Крвне групе” или „Дечака са Мораве”, везују се за овај простор. Музика је убрзо освојила младе генерације, а новоформирани бендови у Чачку су добили место за концерте и, тада изузетно популарне, игранке у Дому JНА. 


\section{(c) (1) $\Theta \Theta$}

Библиотека на сцени: Развој визије Градске библиотеке Чачак као места окупљања заједнице у 2019. години bу Богдан Трифуновић, Марија Радуловић is licensed under a Creative Commons AttributionNonCommercial-NoDerivatives 4.0 International License. 
Усељење Библиотеке 2019. године у адаптиран, реконструисан и проширен простор Дома JНА, значило је окончање вишедеценијског проблема смештаја најстарије установе културе у Чачку. Многобројни старији корисници Библиотеке и суграђани, приликом уласка у нови објекат, коментарисали су како је тај простор изгледао док је функционисао као Дом ЈНА и какав је био рад те установе у домену културе и забаве. Запослени су често имали прилику да чују како се корисници присећају у ком делу зграде су се налазиле куглана и билијар сала, где су се организовале забаве и слушала популарна музика. Нека од сведочанстава суграђана била су почетни импулс и јак мотив за повезивање емоција и сећања на прошло време и простор који данас користи Библиотека. Ова веза огледала се у чињеници да се Библиотека два пута у својој новијој историји усељавала у простор који је пре тога заузимао Дом ЈНА, а што је остало у сећању великог броја суграђана који су користили обе установе. До 1962. године Дом је био смештен у простору зграде познате као „Касина”, у који се 1964. уселила Библиотека и ту остала наредних десет година. А крајем 1962. године изграђена је зграда намењена Дому Југословенске народне армије. Педесет и седам година касније, у адаптиран и реконструисан простор некадашњег Дома ЈНА поново се сели Градска библиотека „Владислав Петковић Дис".

Током свечаности отварања нове зграде Библиотеке, директор установе је окупљенима изложио визију трансформисане институције као места окупљања заједнице и реализације креативних идеја. Том приликом изговорен је и слоган који је осликавао ту визију - „Библиотека на сцени". То је био позив да се искористи значајно уочљивији и повољнији положај установе на културној и друштвеној сцени града, у циљу планирања и реализације идеја које до тада нису биле могуће, или нису у јавности повезиване са радом Градске библиотеке.

\section{Буди наша најјача карика}

Сарадња са партнерима у земљи и иностранству, промоција културне баштине изван локалних или националних оквира, културна дипломатија и слично, постају важни оквири будућег развоја установа из сектора културе. ${ }^{1}$ Томе сведочи и Агенда одрживог развоја Уједињених нација до 2030. године, која не говори директно о култури, али врло јасно упућује на међусекторску сарадњу. Она укључује и чиниоце културног сектора у достизању циљева одрживог развоја, као што су Квалитетно образовање (циљ 4), Афирмација одрживог и инклузивног развоја (8) или Одрживи градови и одрживе заједнице (11).2

Први програм који је укључио ширу друштвену заједницу у активности Библиотеке у 2019. години био је „Буди наша најјача карика - преселимо Библиотеку заједно”. Тада је, у сарадњи са предшколским установама и преко 300 малишана, васпитача, представника Града, полицајаца, библиотекара и случајних пролазника симболично започето пресељење Библиотеке.

Пресељење фондова из просторија Дома културе у Чачку почело је средином јануара 2019. године. Поводом обележавања његовог почетка, Библиотека је, у сарадњи са предшколским установама, 17. јануара 2019. организовала акцију која је симболично истакла значај библиотека за локалну заједницу и означила почетак пресељења књига и инвентара у нови простор у Синђелићевој улици. Тог дана је формиран живи ланац деце предшколског узраста којим су се повезале стара и нова Библиотека. Тако створен ланац малишана, одраслих суграђана, случајних пролазника, радозналих појединаца и библиотекара преносио је књиге из руке у руку и сви заједно су били најјаче карике живог ланца за сељење Библиотеке. Прву књигу током трајања акције, Песме за gецу Јована Јовановића Змаја, примио је градоначелник Чачка,

\footnotetext{
1 Катарина Јаблановић, ур., Међунароgна сараgња библиошека: Зборник раgова сишруної скуйа са међународним уиешћем, Краљево, 3. и 4. окшеобар 2019. (Краљево: Народна библиотека "Стефан Првовенчани", 2019), 7.

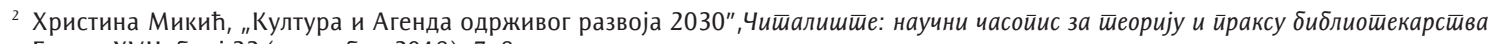
ГодинаXVII, број 33 (новембар 2018): 7-8.
} 
док је директор Библиотеке узео последњу, Малої ирини, Антоана де Сент Егзиперија, чиме је указано на разноврсност, повезаност и богато културно наслеђе светске књижевности за децу и младе.

Овај програм имао је изузетан медијски одјек у земљи и иностранству, чиме је остварена и једна од намера Библиотеке - јавности је усељење установе у нови објекат представљено у контексту значаја за ширу друштвену заједницу, која активно подржава своју најстарију установу културе. Поред тога, уз још 17 примера из целог света, овај догађај је приказан на изложби „Најбоље праксе из библиотека света 2019” (2019 Best Practices From World Libraries Photo Galery) Америчког библиотекарског удружења (American Library Association, ALA), која је као физичка и виртуелна изложба била отворена на ALA конференцији у Вашингтону у јуну 2019. године. ${ }^{3}$

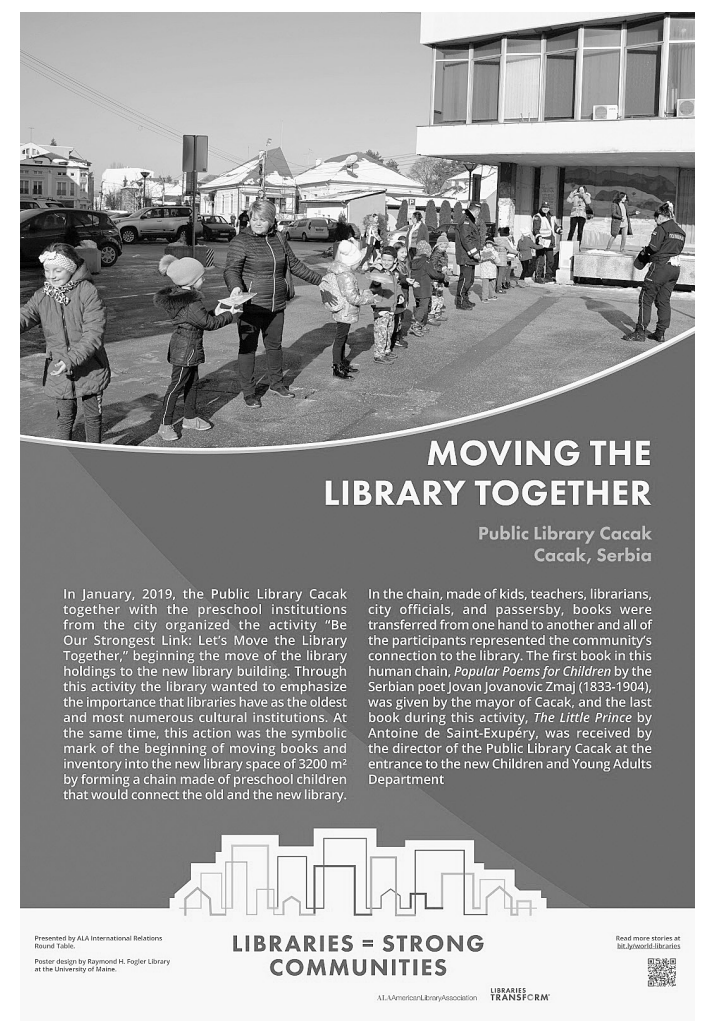

Best Practices From World Libraries, изглед плаката

\section{Библиотека као место носталгије и сећања}

Други догађај који је значајно повезао Библиотеку и ширу друштвену заједницу одржан је у оквиру обележавања Дана европске баштине, септембра 2019. године. Тема манифестације за 2019. годину, „Уметност и забава”, посебно је инспирисала запослене да се баве необичном и недовољно познатом темом, нарочито за млађе суграђане, кроз оживљавање успомена и

\footnotetext{
${ }^{3}$ ALA-IRRT International Connections,"2019 Best Practices from World Libraries Photo Gallery", Google, 27. 5. 2020, https://sites. google.com/view/icc-programs/2019-photo-gallery.

Више детаља у Grace Liu, Mark Mattson, "Best Practices from World Libraries Photo Gallery Project: Engaging Global Libraries", International Information \& Library Review Volume 52, Issue 1(2020): 73-78.
} 
упознавање нових генерација са забавом која се одвијала у Дому ЈНА 60-тих година 20. века. Прикупљена сећања, документи и фотографије Чачана приказани су на мултимедијалној изложби „Ко некад у осам”, након чега је одржан концерт музике из времена 60-их година 20. века, за преко 300 посетилаца.

Идеја прикупљања породичних меморабилија и сећања појединаца на одређени историјски период и догађаје који су га обележили, у Градској библиотеци „Владислав Петковић Дис” није нова. Библиотека је раније стекла искуство кроз учешће у пројекту Мобилизација сећања који је реализован под покровитељством мреже Europeana током 2014. године, а у сарадњи са градским библиотекама у Београду и Новом Саду. У основи овог пројекта било је прикупљање породичних сећања и ратних артефаката из Првог светског рата, њихова дигитална заштита, као и промоција локалног и националног културног наслеђа. ${ }^{4}$ Осим стеченог искуства у самим оперативним процедурама прикупљања сећања, поменути пројекат је показао на који начин библиотека може прећи из улоге пасивног чиниоца у улогу директног актера у сакупљању, чувању, анализи и презентацији грађе. Овај модел је успешно примењен и када је, након отварања нове зграде Библиотеке, завладало велико интересовање грађана за нову кућу најстарије установе културе у Чачку. Све то је инспирисало ауторе изложбе Богдана Трифуновића и Марију Радуловић да што детаљније истраже и сазнају како је изгледала забава средином прошлог века у овом простору и граду на Морави. Испоставило се да нема много сачуваног материјала и архивске грађе, јер је војни карактер Дома ЈНА условио и посебне процедуре чувања документације везане за рад ове установе, до које аутори нису успели да дођу у комуникацији са надлежним органима Министарства одбране.

Библиотека је, у оквиру рада Завичајног одељења, деценијама сакупљала и чувала некњижну грађу везану за културну историју града, као што су фотографије, плакати, позивнице, али о самом Дому ЈНА било је изузетно мало грађе. Друге установе културе, Народни музеј Чачак и Међуопштински историјски архив, нису располагале значајнијим фондом грађе, осим одређеног броја плаката, који су неселективно прикупљани. Суочивши се са оскудним сачуваним материјалом у установама, аутори су прибегли методи ангажовања локалне заједнице и појединаца, да се из личних и породичних албума и успомена искористе делови сећања који могу да помогну у реализацији идеје. Из тог разлога је осмишљено да библиотекари искористе материјална и нематеријална сећања суграђана кроз посебно организовану активност прикупљања грађе.

\section{Дан прикупљања сећања}

Дан йрикуйљања сећања на Дом ЛНА и забаву у Чачку је реализован 17. септембра 2019. у оквиру манифестације Дани евройске башйине 2019. Суграђане је било потребно обавестити, мотивисати и окупити око иницијалне идеје да са библиотекарима поделе своје успомене. На позив из Библиотеке одазвало се више од 30 суграђана: пензионисана војна лица, њихови потомци и породице, цивилна лица која су била запослена при Дому JНА, чланице некадашњег Клуба жена који је постојао у оквиру Дома, суграђани који су посећивали забаве или концерте итд. Они су донели фотографије, позивнице, плакате и друге предмете, или испричали своје успомене на године када су у Дому ЈНА организоване забаве, игранке, концерти, матинеи, изложбе и други културно-забавни садржаји. Том приликом је дигитализовано више од 150 фотографија које су постале део фонда Завичајног одељења, док су оригинали враћени власницима. Камером је забележено петнаест личних прича и драгоцених сећања из прошлости Чачка. ${ }^{5}$ Грађа која је

\footnotetext{
${ }^{4}$ Мирко Дрманац и Александар Вукајловић, „Мобилизација сећања - прикупљање и дигитализација историјске грађе”, Глас библиошеке број 22 (2016): 159-174.

${ }^{5}$ Gradska biblioteka "Vladislav Petković Dis", „Sećanje na zabavu u Domu JNA Čačak”, Youtube, 27. 5. 2020, https://www.youtube. com/watch?v=F085JJuls_k
} 
на овај начин трајно отргнута од заборава, индивидуална сећања старих Чачана, фотографије, новински чланци и други предмети постали су основа изложбе „Ко некад у осам”.

Локални и регионални медији су Дан ирикуйљања сећања на Дом ЛНА и забаву у Чачку најавили и пратили снимљеним прилозима и изјавама учесника, а Библиотека је искористила прилику да јавности скрене пажњу на себе као место новог генерацијског сусретања, повезивања и дељења успомена, као и на предстојећи програм намењен широј друштвеној заједници.

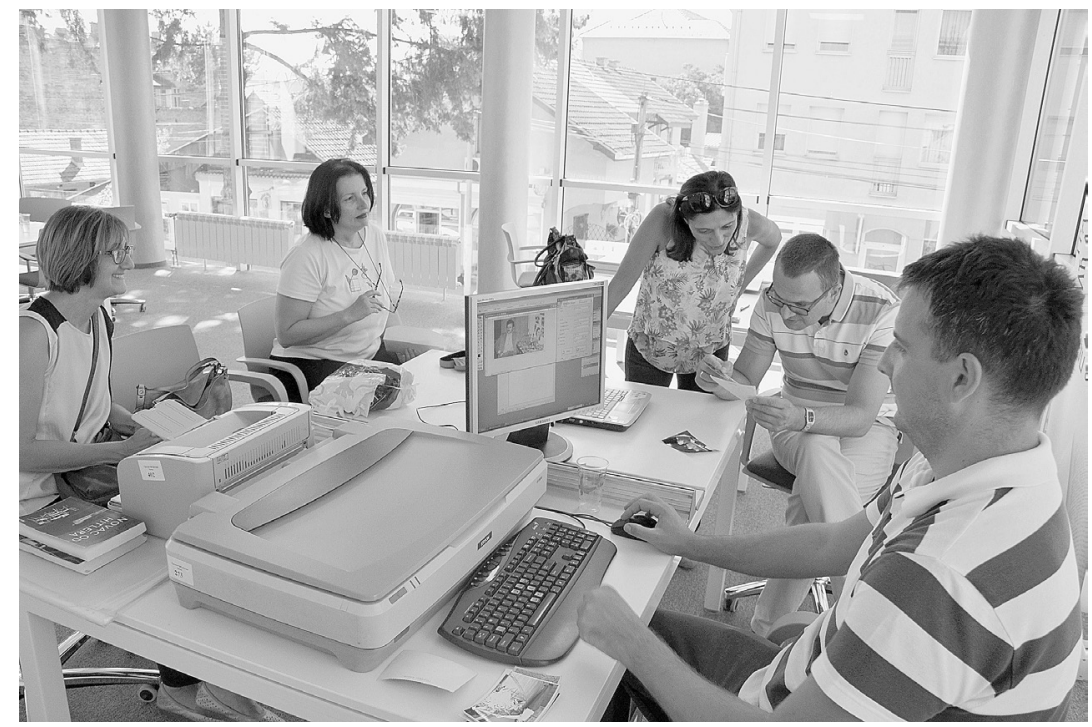

Кад потомци прегледају породичне албуме - Дан прикупљања сећања

\section{Ко некад у осам}

Уз помоћ прикупљеног материјала и других документа било је могуће реализовати идеју и направити мултимедијалну изложбену поставку "Ко некад у осам". Народни музеј и Међуопштински историјски архив у Чачку позајмили су Библиотеци предмете из својих фондова који припадају периоду шездесетих, као што су мушки и женски одевни предмети и рекламни плакати за програме који су организовани у Дому ЈНА. Заинтересовани појединци су уступили грамофон са плочама, стару гитару, билијарски штап, фотографске апарате и фотографије. Обједињавањем већег броја прикупљених индивидуалних сећања, допуњених избором фотографија, новинским натписима, плакатима и другом грађом, приказано је и својеврсно колективно сећање Чачана о забави у граду 60-их и 70-их година, као и емотивна димензија наслеђа једног времена.

Изложбу „Ко некад у осам" чинило је неколико сегмената, међу којима доминирају плакати, велике копије оригиналних плаката из времена 60-их и увеличане фотографије. Цитати, фотографије, прес-клипинг, позивнице и др. су тематски распоређени и груписани. Сваки од њих, попут времеплова, публику уводи у контекст времена, информише о историјату Дома JНА, представља врсте тада актуелних културно-забавних или спортских садржаја који су били доступни у Дому ЈНА. Посебно место у изложбеном простору добили су плакати посвећени музичким догађајима, плесу, забавама, матурским вечерима, новогодишњим прославама и др.

Други сегмент изложбе чинили су оригинални предмети из времена 60-их година прошлог века из збирке Народног музеја Чачак. У изложбеним витринама и на постаментима могли су се видети књиге, радио-апарат, камера, гитара, фото-апарат, плоче, грамофон, украсни предмети, костимиране лутке, так за билијар и др. 
Кроз трећи сегмент изложбе приказани су видео-записи суграђана који су током Дана прикупљања сећања испричали занимљивости о Дому JНА и прикупљене фотографије, што је привукло велику пажњу присутних на отварању изложбе.

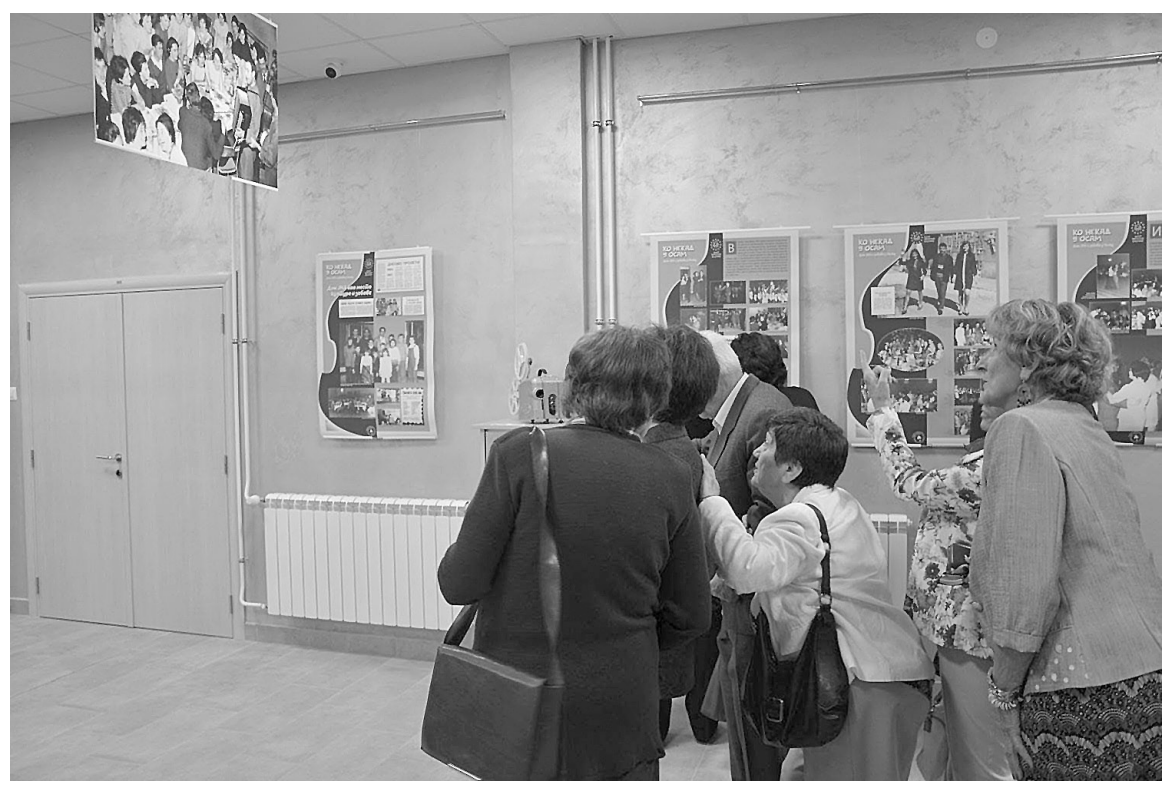

Поглед на матурско вече са носталгијом - са отварања изложбе

Усмеравањем пажње јавности на везу Библиотеке и Дома JНА настојало се да се локална заједница ангажује на прикупљању сећања кроз евоцирање успомена старијих генерација и њихово презентовање на изложби која је представљала најважнији сегмент програма. На тај начин се оскудна сачувана материјална грађа о Дому JНА допунила личним предметима, причама и усменим сећањима савременика, који најчешће са сетом и пијететом причају о периоду шездесетих и седамдесетих година, када је Дом JНА био најзначајнији центар културе у граду. Довођењем у везу некадашњег Дома JНА и модерне јавне библиотеке грађани су препознали важност иницијативе за чување и презентацију важног периода културне историје града. Тиме је последично и завичајна културна баштина коју Библиотека чува значајно обогаћена кроз дигитализоване фотографије, позивнице, плакате, чланске карте или снимљена усмена сведочанства савременика.

\section{Закључна разматрања - сарадња као кључ успеха}

Описани примери остварене сарадње на измењеним основама функционисања, као што је усељење у нови простор, у контексту чачанске Библиотеке јасно показују неопходност ширења спектра потенцијалних партнера које би библиотеке требало да контактирају, било да су у питању разлози очувања и презентације културне баштине, утицаја на јавно мњење, заговарање, програмске иницијативе или сви ови разлози заједно. Током девет месеци 2019. године, Градска библиотека у Чачку покренула је иницијативе које су довеле до ширења сарадње са постојећим партнерима, као што су установе културе и предшколског образовања, или остварила нове контакте и сарадњу са појединцима и организацијама цивилног друштва. Без сарадње и конкретне помоћи у реализацији програма, а што је било мотивисано промишљеним наступом установе у промовисању заједничке културне баштине, односно општег интереса за заједницу, иницијатива „Библиотека на сцени" ни приближно не би имала ефекта. 
Библиотека је постала место окупљања своје заједнице, нарочито видљиво у програмској тј. културно-образовној делатности, што је несумњиво позитивно утицало и на повећање броја чланова, односно већу позајмицу грађе. ${ }^{6}$ Нова визија била је изузетно ефектно преточена у програм „Буди наша најјача карика”, који је повезао и усмерио пажњу заједнице на установу кроз остварење заједничког циља. Са друге стране, тема локалног или завичајног културноисторијског наслеђа у вези са објектом некадашњег Дома ЈНА врло је успешно искоришћена за јачање сарадње или стварање нових партнерстава са појединцима и организацијама који раније нису била активни партнери. Успешно мотивишући многобројне суграђане да учествују у Дану ирикуйљања сећања на Дом ЈНА и забаву у Чачку, аутори програма су кроз сарадњу са појединицима, установама и колегама приредили изложбу која је привукла најбројнију публику за једно вече у Библиотеци током 2019. године.

Сарадња са удружењима, организацијама, установама, као и широм друштвеном заједницом кроз наведене програмске активности била је у функцији остваривања нове визије и дала је одличне резултате. Осим већ споменутог пораста броја активних чланова Библиотеке, евидентан је раст публике на осталим програмима, али и промењена перцепција јавне библиотеке као модерне установе културе која се трансформише сагледавајући потребе и интересовања локалне заједнице. ${ }^{7}$ У домену библиотечке струке ови примери сарадње са друштвеном заједницом су значајни као подстицај и практичне смернице другим библиотекама у ангажовању локалне заједнице на очувању, промовисању и афирмисању завичајне баштине на модеран и за ширу јавност атрактиван начин, а све ово заједно доприноси изградњи новог имиџа и визије развоја библиотека као центара окупљања својих заједница.

\section{Литература и извори:}

1. ALA-IRRT International Connections. "2019 Best Practices from World Libraries Photo Gallery". Google, 27. 5. 2020, preuzeto 15. 10. 2020, https://sites.google.com/view/ icc-programs/2019-photo-gallery.

2. COBISS. „Podaci o broju članova biblioteke i korišćenju usluga COBISS/Pozajmice za period 1. 1. 2019-31. 12. 2019. na dan 31. 12. 2019". IZUM - Institut informacijskih znanosti. Preuzeto 27. 5. 2020. http://sr.cobiss.net/pokazatelji/doc/STAT_POZAJMICA_2019_SR_cir.pdf.

3. Drmanac, Mirko i Aleksandar Vukajlović. "Mobilizacija sećanja-prikupljanje i digitalizacija istorijske građe". Glas biblioteke broj 22 (2016): 159-174.

4. Gradska biblioteka „Vladislav Petković Dis". "Sećanje na zabavu u Domu JNA Čačak”. Youtube, 27. 5. 2020, https://www.youtube.com/watch?v=F085JJuls_k.

5. Jablanović, Katarina, ur. Međunarodna saradnja biblioteka Zbornik radova stručnog skupa sa međunarodnim učešćem, Kraljevo 3. i 4. oktobar 2019. Kraljevo: Narodna biblioteka "Stefan Prvovenčani" Kraljevo, 2019.

6. Liu, Grace and Mark Mattson."Best Practices from World Libraries Photo Gallery Project: Engaging Global Libraries". International Information \& Library Review Volume 52, Issue 1(2020): 73-78.

7. Mikić, Hristina. "Kultura i Agenda održivog razvoja 2030". Čitalište: naučni časopis za teoriju i praksu bibliotekarstva Godina XVII, broj 33 (novembar 2018): 3-15.

\footnotetext{
${ }^{6}$ О учинку Библиотеке у 2019. години можда најбоље сведоче бројке. Библиотечка статистика за 2019. годину мреже Cobiss.sr, показује да је чачанска Библиотека, упркос чињеници да је 2019. године, због пресељења у нову зграду, почела рад са корисницима 28. марта, имала 7917 активних чланова, по чему је најуспешнија јавна библиотека и друга библиотека у оквиру целокупне мреже, одмах иза Народне библиотеке Србије. По броју позајмљених публикација, Градска библиотека је на другом месту међу јавним библиотекама које су у Cobiss мрежи. - COBISS, „Подаци о броју чланова библиотеке и коришћењу услуга COBISS/Позајмице за период 1. 1. 2019-31. 12. 2019. (на дан 31. 12. 2019)", IZUM - Институт информацијских знаности, преузето 27.5 2020, http://sr.cobiss.net/pokazatelji/doc/STAT_POZAJMICA_2019_SR_cir.pdf.

7 Јаблановић, Међунароgна сараяња библиоиекка, 7.
} 


\title{
Library on the Stage: Development of the Vision of the Čačak City Library as 2019 Community Gathering Place
}

\begin{abstract}
Summary
The paper presents innovative programs and activities of the City Library Vladislav Petković Dis in Čačak that were realized through partnership with the wider community, as a basis for the development of a new vision of the library, whose motto is Library on the Stage. The new library building was opened in March 2019, in an effort to become a local community gathering center, and thus expand its capacity. It was promoted in an attractive and unusual way, with the programs Be Our Strongest Link: Let's Move the Library Together, and As Once at Eight: The Home of the YPA and Entertainment in Čačak, which brought the building into the sphere of interest of individuals who had never used the library services before. The programs were organized in the function of developing a new vision of the library, as well as more intensive cooperation with individuals, associations, organizations, etc. This has led to an increase in the number of active members of the library, a larger audience on its other programs and a significantly greater presence of the institution in the public and media space of the local community.
\end{abstract}

Keywords: City Library Vladislav Petković Dis, Čačak, public relations, cooperation, partnerships, local heritage, exhibitions, programs 


\section{(c) (1) $\Theta \Theta$}

Библиотека на сцени: Развој визије Градске библиотеке Чачак као места окупљања заједнице у 2019. години bу Богдан Трифуновић, Марија Радуловић is licensed under a Creative Commons AttributionNonCommercial-NoDerivatives 4.0 International License. 